\title{
Implementasi Program Pelayanan One Day Service dalam Meningkatkan Kualitas Pelayanan Badan Pertanahan Nasional Kota
}

\author{
Ariska Tri Viky Andani ${ }^{a} *$, Endah Setyowati ${ }^{\mathrm{b}}$, Fadillah Amin ${ }^{\mathrm{c}}$ \\ ${ }^{a b c}$ Universitas Brawijaya, Malang, Jawa Timur, Indonesia
}

\section{INFORMASI ARTIKEL}

\section{Article history:}

Dikirim tanggal: 17 Juni 2019

Revisi pertama tanggal: 25 November 2019

Diterima tanggal: 03 Desember 2019

Tersedia online tanggal: 24 Desember 2019

Keywords: public service, defense, one day service

\section{ABSTRACT}

Public service is one of the important things that becomes a benchmark in the implementation of government administration as a manifestation of creating quality public services. The problem in public service is a burden for the government because many complaints are received by the government on the implementation of public services, especially in the field of land, services about land services that seem convoluted and require a long time. Head of Land Agency Regulation No. 1 of 2010 as an effort to respond to poor service by the National Land Agency of the Republic of Indonesia through accelerated public service programs in the land sector, one of which is One Day Service for Land Services or one-day service that can be carried out throughout the Agency's work area National Land all over Indonesia. It is expected that this program can improve the quality of public services in the field of land so that public services in the land sector become a quality and effective and efficient service.

\section{INTISARI}

Pelayanan publik merupakan salah satu hal penting yang menjadi sebuah tolak ukur pada pelaksanaan administrasi pemerintahan sebagai wujud menciptakan pelayanan publik yang berkualitas. Permasalahan dalam pelayanan publik menjadi sebuah beban tersendiri bagi pemerintah karena banyak keluhan yang diterima oleh pemerintah akan pelaksanaan pelayanan publik khususnya pada bidang pertanahan, banyaknya keluhan atas pelayanan pertanahan yang terkesan berbelitbelit dan membutuhkan waktu yang lama. Peraturan Kepala Badan Pertanahan Nomor 1 Tahun 2010 sebagai upaya untuk merespon atas buruknya pelayanan oleh Badan Pertanahan Nasional Republik Indonesia, yaitu melalui program percepatan pelayanan publik bidang pertanahan salah satunya, yaitu Pelayanan One Day Service Pertanahan atau pelayanan satu hari selesai yang dapat dilakukan diseluruh wilayah kerja Badan Pertanahan Nasional. Diharapkan dengan adanya program ini dapat meningkatkan kualitas pelayanan publik dibidang pertanahan sehingga pelayanan publik dibidang pertanahan menjadi sebuah pelayanan yang berkualitas dan efektif serta efisien. 


\section{Pendahuluan}

Pelayanan publik menjadi salah satu bagian penting dalam berjalannya roda pemerintahan. Pelayanan publik dan birokrasi pemerintahan tidak dapat terlepas karena satu sama lainnya saling berkaitan. Perbaikan birokrasi pemerintah dimulai dari perbaikan pelayanan kepada masyarakat serta perbaikan pelayanan publik dimulai dengan melibatkan beberapa pihak swasta agar masyarakat mendapatkan pelayanan publik yang berkualitas dan lebih baik. Salah satu pelayanan publik yang direformasi oleh pemerintah adalah pelayanan pertanahan. Hal tersebut disebabkan peran pertanahan merupakan salah satu kebutuhan masyarakat dan menimbulkan permasalahan pelayanan pertanahan mengingat meningkatnya kebutuhan masyarakat akan tanah sebagai salah satu nilai ekonomis.

Menurut Effendi (1993) dijelaskan bahwa tanah, air dan udara serta kekayaan alam yang terkandung didalamnya untuk kesejahteraan rakyat, dan melaksanakan hak dan kewajiban yang diperolehnya sesuai dengan peraturan yang telah memberikan jaminan kepastian perlindungan terhadap hak dan kewajiban masyarakat.

Oleh sebab itu untuk memberikan perlindungan hak dan kewajiban kepada masyarakat akan persoalan pertanahan, maka pemerintah melakukan perbaikan terhadap pelayanan pertanahan melalui reformasi birokrasi di Badan Pertanahan Nasional sebagai salah satu tanggung jawab pemerintah akan respon buruk masyarakat terhadap pelayanan pertanahan. Evaluasi pelayanan oleh Ombudsman menempatkan pelayanan pertanahan sebagai salah satu instansi yang memberikan pelayanan tidak maksimal dengan jumlah laporan masuk sebanyak 530 laporan meningkat dari Tahun 2013 hanya 365 laporan.

Dengan adanya peningkatan kebutuhan akan tanah sebagai salah satu nilai ekonomis, maka Badan Pertanahan Nasional Republik Indonesia perlu melakukan reformasi birokrasi pada organisasi pertanahan diseluruh wilayah kerja Badan Pertanahan Nasional. Selain itu, pemerintah juga perlu melakukan penataan ulang konsep pelayanan publik yang menjadi bahasan mengenai reformasi birokrasi. Menurut Setyaningrum (2009:80), demokrasi yang berkembang ditengah masyarakat menyebabkan masyarakat dapat memberikan penilaian terhadap pelayanan publik yang diterimanya. Oleh sebab itu, adanya pelaksanaan reformasi birokrasi menjadikan fungsi pemerintah dan aparatur negara sebagai public servant atau terobosan baru dalam pelayanan publik melalui inovasi-inovasi pelayanan.

Reformasi birokrasi yang dilakukan oleh Badan Pertanahan Nasional Kota Malang sebagai upaya dalam perbaikan pelayanan publik dibidang pertanahan; adalah melalui program percepatan pelayanan, yaitu Program
One Day Service atau pelayanan satu hari selesai. Program pelayanan tersebut dilaksanakan setiap hari Rabu. Harapan dari adanya program ini adalah terpangkasnya waktu pelayanan yang birokratis dan membutuhkan waktu yang lama. Selain itu dengan adanya program One Day Service di Badan Pertanahan Nasional Kota Malang dapat menjadi sarana bagi pemerintah untuk menciptakan pelayanan kepada masyarakat yang berkualitas, efektif dan efisien.

Berdasarkan uraian diatas, maka peneliti tertarik untuk melakukan penelitian mengenai implementasi Program One Day Service di Badan Pertanahan Nasional Kota Malang yang mencakup kualitas penerapan Program One Day Service dan faktor-faktor pendukung dan penghambat pelaksanaan Program One Day Service di Badan Pertanahan Nasional Kota Malang.

\section{Teori}

\subsection{Implementasi}

Grindle (1980:7) menyatakan, implementasi merupakan proses umum tindakan administratif yang dapat diteliti pada tingkat program tertentu. Sedangkan Van Meter \& Horn (Wibawa dkk, 1994:15) menyatakan bahwa implementasi kebijakan merupakan tindakan yang dilakukan oleh pemerintah dan swasta baik secara individu maupun secara kelompok yang dimaksudkan untuk mencapai tujuan. Grindle (1980:7) menambahkan bahwa proses implementasi baru akan dimulai apabila tujuan dan sasaran telah ditetapkan, program kegiatan telah tersusun, dan dana telah siap serta telah disalurkan untuk mencapai sasaran.

Implementasi suatu program merupakan suatu yang kompleks, dikarenakan banyak faktor yang saling berpengaruh dalam sebuah sistem yang tidak lepas dari faktor lingkungan yang cenderung selalu berubah. Donald P. Warwick dalam Syukur (1988), mengatakan bahwa dalam tahap implementasi program terdapat dua faktor yang mempengaruhi keberhasilan, yaitu faktor pendorong (faciliting conditions) dan faktor penghambat (impending conditions).

\subsection{Program}

Program didalam Kamus Bahasa Indonesia didefinisikan sebagai rancangan mengenai asas-asas serta usaha-usaha yang akan dijalankan (Departemen Pendidikan Nasional, 2008). Jones dalam Rohman (2009:101-102) menyebutkan bahwa program merupakan salah satu komponen dalam suatu kebijakan. Program merupakan upaya berwenang untuk mencapai tujuan.

Program merupakan unsur pertama yang harus ada demi tercapainya kegiatan implementasi. Unsur kedua yang harus terpenuhi dalam proses implementasi 
program yaitu adanya kelompok masyarakat yang menjadi sasaran program, sehingga masyarakat dilibatkan dan membawa hasil dari program yang dijalankan dan adanya perubahan dan peningkatan dalam kehidupannya. Tanpa memberikan manfaat kepada masyarakat maka dikatakan program tersebut gagal dilaksanakan. Berhasil atau tidaknya suatu program diimplementasikan tergantung dari unsur pelaksananya (eksekutif).

Unsur pelaksana ini merupakan unsur ketiga. Pelaksanaan penting artinya karena pelaksanaan baik itu organisasi maupun perorangan bertanggung jawab dalam pengelolaan maupun pengawasan dalam proses implementasi (Riggs, 2005:54). Guna mencapai sebuah tujuan implementasi program secara efektif, pemerintah harus melakukan aksi atau tindakan yang berupa penghimpunan sumber dana dan pengelolaan sumber daya alam dan manusia.

Hasil yang diperoleh dari aksi pertama dapat disebut input kebijakan, sementara aksi yang kedua disebut sebagai proses implementasi kebijakan (Ratmiko \& Winarsih, 2005:4). Untuk mengoperasikan implementasi program agar tercapainya suatu tujuan serta terpenuhinya misi program diperlukan kemampuan yang tinggi pada organisasi pelaksanaannya.

\subsection{Implementasi Program}

Implementasi merupakan suatu proses yang sangat penting ketika membicarakan mengenai penerapan program, baik yang bersifat sosial atau dalam dunia pendidikan. Implementasi program merupakan langkahlangkah pelaksanaan kegiatan dalam upaya mencapai tujuan dari program itu sendiri (Jones dalam Rohman, 2009:101-102). Salah satu model implementasi program, yakni model yang diungkapkan oleh David C. Korten (Akib \& Tarigan, 2008). Model ini memakai pendekatan proses pembelajaran dan lebih dikenal dengan model kesesuaian implementasi program. Model Kesesuaian Korten digambarkan sebagai berikut:

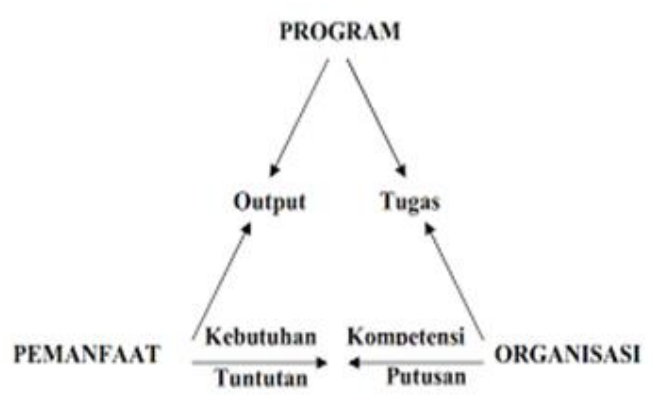

Gambar 1 Model Kesesuaian Implementasi Program David C Korten

Sumber: Akib \& Tarigan, 2008

Korten menyatakan bahwa suatu program akan berhasil dilaksanakan jika terdapat kesesuaian dari tiga unsur implementasi program, yaitu sebagai berikut (Akib \& Tarigan, 2008:12): a) Kesesuaian antara program dan pemanfaatan, yaitu kesesuaian antara apa yang ditawarkan oleh program dengan apa yang dibutuhkan oleh kelompok sasaran (pemanfaat);

b) Kesesuaian antara program dengan organisasi pelaksana, yaitu kesesuaian antara tugas yang diisyaratkan oleh program dengan kemampuan organisasi pelaksana; dan

c) Kesesuaian antara kelompok pemanfaat dengan organisasi pelaksana, yaitu kesesuaian antara syarat yang diputuskan organisasi untuk dapat memperoleh output program dengan apa yang dapat dilakukan oleh sekelompok sasaran program.

\subsection{Pelayanan Publik}

Pelayanan publik menjadi konsep yang sering digunakan oleh banyak pihak, baik dari kalangan praktisi mapun ilmuwan, dengan makna yang berbedabeda. Dalam sejarah perjalanan administrasi publik, pelayanan publik semula dipahami secara sederhana sebagai pelayanan yang diselenggarakan oleh pemeriantah. Semua barang dan jasa yang diselenggarakan oleh pemerintah kemudian disebut sebagai pelayanan publik. Literatur terdahulu umumnya menjelaskan bahwa "whatever government does is public service" (Dwiyanto, 2010:14).

Secara universal karakteristik pelayanan publik menurut Alamsyah (2011:366-368) dapat dirincikan, yaitu sebagai berikut:

a) Pelayanan publik berorientasi kepentingan publik;

b) Konsenkuensi ciri pelayanan publik berorientasi kepentingan publik adalah para pelayan publik tidak boleh bebas nilai (value free);

c) Proses pelayanan publik itu harus partisipatif dan memberdayakan, ekonomis (efisiensi, efektif, dan produktif), berkeadilan sosial dan ekologis, serta akuntabel;

d) Tindakan para pelayan publik mempertimbangkan etika; dan

e) Sistem dan proses pelayanan publik dibangun atas dasar aturan, hukum, dan kesepakatan tertentu.

\subsection{Kualitas Pelayanan Publik}

Menurut Brady dan Conin dijelaskan bahwa kualitas pelayanan merupakan perbandingan antara kenyataan atas pelayanan yang diterima dengan harapan atas pelayanan yang ingin diterima (Afrizal, 2009:88). Sedangkan ditambahkan oleh Parasuraman, Zeithaml \& Berry dalam Samosir (2005:28) bahwa:

Kualitas pelayanan adalah perbandingan yang diharapkan konsumen dengan pelayanan yang diterimanya.

Berdasarkan pengertian tersebut, maka dapat dipahami bahwa masyarakat dalam memberikan penilaian terhadap kualitas pelayanan berdasarkan perbandingan 
pengalaman yang pernah dirasakan dengan apa yang diharapkan atas pelayanan tersebut. Seperti yang dijelaskan sebelumnya bahwa didalam suatu organisasi, konsep kualitas pelayanan menjadi ukuran keberhasilan organisasi yang dimaksud baik itu pada organisasi bisnis maupun juga pada organisasi yang bertugas untuk menyediakan pelayanan publik.

Dimensi yang dapat digunakan sebagai pedoman untuk mengukur kualitas pelayanan publik menurut Zethaml, Parasuraman \& Berry (dalam Pasolong, 2013:135) dapat diuraikan sebagai berikut:

a) Tangibles (Berwujud Fisik)

Kualitas pelayanan berupa sarana fisik perkantoran, komputerisasi administrasi, ruang tunggu, tempat informasi. Indikator dimensi tangibles (bukti langsung/ berwujud).

- Penampilan petugas, aparatur dalam melayani masyarakat;

- Kenyamanan tempat melakukan pelayanan;

- Kedisiplinan petugas/ aparatur dalam melakukan pelayanan;

- Kemudahan proses dan akses pelayanan; dan

- Penggunaan alat bantu dalam pelayanan.

b) Reability (Kehandalan)

Kemampuan dan keandalan untuk menyediakan pelayanan yang terpercaya. Indikator dimensi realibility (kehandalan), yaitu terdiri dari:

- Kecermatan petugas dalam melayani masyarakat;

- Memilik standar pelayanan yang jelas;

- Kemampuan petugas/ aparatur dalam menggunakan alat bantu dalam proses pelayanan; dan

- Keahlian petugas dalam menggunakan alat bantu dalam proses pelayanan.

c) Responsiveness (Ketanggapan)

Kesanggupan untuk membantu dan menyediakan pelayanan secara cepat dan tepat, serta tanggap terhadap keinginan konsumen. Indikator dimensi responsiveness (respon/ ketanggapan), yaitu sebagai berikut:

- Merespon setiap pelanggan/ pemohon yang ingin mendapatkan pelayanan;

- Petugas/ aparatur melakukan pelayanan dengan cepat dan tepat;

- Petugas/ aparatur melakukan pelayanna dengan cermat; dan

- Semua keluhan pelanggan direspon oleh petugas.

d) Assurance (Jaminan)

Kemampuan dan keramahan serta sopan santun pegawai dalam menyakinkan kepercayaan konsumen. Indikator dimensi assurance (jaminan) terdiri atas indikator, antara lain sebagai berikut:

- Petugas memberikan jaminan tepat waktu dalam pelayanan;
- Petugas memberikan jaminan legalitas dalam pelayanan; dan

- Petugas memberikan jaminan kepastian biaya dalam pelayanan.

e) Emphaty (Kepedulian dan Bersedia Memberikan Perhatian kepada Pemohon)

Mencakuup kemudahan dalam melakukan hubungan komunikasi yang baik dan memahami kebutuhan masyarakat. Indikator dimensi emphaty (empati) terdiri atas indikator, yaitu sebagai berikut:

- Mendahaulukan kepentingan pemohon/ masyarakat;

- Petugas melayani dengan sikap ramah;

- Petugas melayani dengan sikap sopan santun;

- Petugas melayani dengan tidak diskriminatif (membeda-bedakan); dan

- Petugas melayani dan menghargai setiap pemohon/ masyarakat.

\section{Metode Penelitian}

Penelitian ini menggunakan penelitian kualitatif dengan pendekatan deskriptif. Hal tersebut berorientasi pada sebab akibat yang bersifat ilmiah. Dalam penelitian ini digunakan penelitian kualitatif yang didefiniskan sebagai proses penelitian yang ditujukan untuk memahami permasalahan manusia dalam konteks sosial dengan cara menyajikan gambaran yang menyeluruh, melaporkan pandangan terperinci dari para narasumber, serta dilakukan setting yang alamiah tanpa adanya intervensi apapun dari peneliti (Creswell dalam Herdiansyah, 2010:8).

Adapun fokus dalam penelitian ini, yaitu sebagai berikut:

a) Implementasi Program Pelayanan One Day Service di Badan Pertanahan Nasional Kota Malang; dan

b) Faktor pendukung dan penghambat dalam implementasi Program One Day Service di Badan Pertanahan Nasional Kota Malang.

Lokasi penelitian ini berada di Badan Pertanahan Nasional Kota Malang. Pemilihan lokasi ini menarik bagi peneliti karena pelaksanaan pelayanan pertanahan melalui Program One Day Service di Kota Malang yang sudah berjalan dengan baik akan tetapi didalamnya masih terdapat kendalam dalam pelaksanaanya.

Sumber data dalam penelitian ini adalah pegawai Badan Pertanahan Kota Malang, Renstra Badan Pertanahan Kota Malang. Instrumen penelitian yang digunakan, yaitu peneliti sendiri dan pedoman wawancara penelitian (kamera).

Analisis data dalam penelitian ini menggunakan analisis Miles, Hubberman \& Saldana (2014:33). Analisis data model interaktif menurut Miles, Hubberman \& Saldana adalah pengumpulan data, kondensasi data, penyajian data serta menarik kesimpulan dan diversifikasi. 


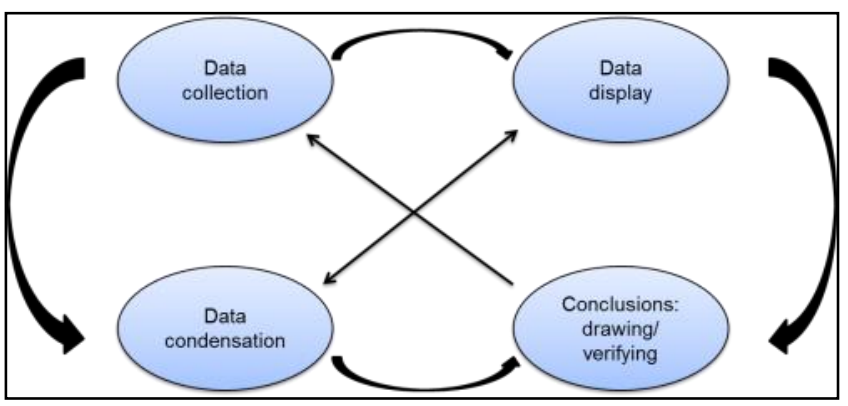

Gambar 2 Interactive Model of Data Analysis Sumber: Miles, Hubberman \& Saldana (2014:33)

\section{Hasil Penelitian dan Pembahasan}

\subsection{Implementasi Program One Day Service di Badan Pertanahan Nasional Kota Malang}

Berdasarkan model implementasi program, yakni model yang diungkapkan oleh David C. Korten; maka model ini menggunakan pendekatan proses pembelajaran dan lebih dikenal dengan model kesesuaian implementasi program. Model kesesuaian implementasi program oleh David C. Korten serta implementasi pelaksanaan program One Day Service Badan Pertanahan Nasional Kota Malang; dapat diuraikan sebagai berikut:

\subsubsection{Kesesuaian antara Program dengan Pemanfaat}

a) Adanya Kejelasan Program dengan Masyarakat

Tahapan pada pelaksanaan pelayanan One Day Service, yaitu kesesuaian Program One Day Service dengan masyarakat sebagai penerima pelayanan pertanahan. Kejelasan program pada pelayanan One Day Service disampaikan melalui kegiatan sosialisasi dan penyebaran informasi melalui website resmi Badan Pertanahan Nasional Republik Indonesia. Meskipun telah dilakukan proses sosialisasi dan penyebaran informasi melalui media online, akan tetapi Program One Day Service masih kurang dipahami oleh masyarakat. Hal tersebut dibuktikan dengan masih ada masyarakat yang mengeluhkan mengenai prosedur dan syarat permohonan pelayanan yang masih tidak lengkap pada saat berada diloket penerimaan berkas permohonan. Kejelasan Program One Day Service telah berjalan dengan efektif dan efisien menurut Kepala Tata Usaha Badan Pertanahan Kota Malang, akan tetapi pada kenyataannya masih ada sebagain besar masyarakat yang tidak memahami dan mengerti mengenai persyaratan dan prosedur pelayanan pertanahan melalui program ini dan tidak maksimalnya proses sosialisasi dan penyuluhan yang diberikan oleh pegawai Badan Pertanahan Nasional Kota Malang. b) Kesesuaian Program dengan yang Dibutuhkan oleh Masyarakat

Pelaksanaan pelayanan pertanahan melalui Program One Day Service menjadi salah satu jawaban atas keluhan masyarakat akan buruknya pelayanan pertanahan yang selama ini membutuhkan waktu yang cukup lama dan proses pelaksanaan pelayanan yang terkesan berbelit-belit, sehingga menyebabkan masyarakat melakukan pelayanan melalui calo atau perantara. Adanya program ini sesuai dengan apa yang dibutuhkan serta sebagai upaya untuk meningkatkan tingkat partisipatif masyarakat agar datang sendiri untuk mengurus dokumen pertanahan.

\subsubsection{Kesesuaian Antara Progran dengan Organisasi Pelaksana}

a) Kemampuan Pegawai dalam Melaksanakan Program One Day Service

Kemampuan pegawai dalam melaksanakan pelayanan pertanahan pada Program One Day Service di Badan Pertanahan Nasional Kota Malang merupakan salah satu unsur penting dalam sebuah pelayanan publik. Selain itu pemahaman petugas mengenai prosedur pelayanan One Day Service sangat dibutuhkan mengingat pemahaman tersebut merupakan langkah pertama untuk meminimalisirkan kesalahan atas prosedur pelayanan One Day Service pertanahan. Kemampuan petugas di Badan Pertanahan Nasional Kota Malang dalam melayani masyarakat cukup baik dan mereka memahami mengenai persyaratan dan prosedur yang dibutuhkan dalam pelayanan pertanahan. Selama proses pelayanan pertanahan, petugas Badan Pertanahan Nasional Kota Malang tidak mengalami hambatan yang berarti baik saat berlangsungnya pelayanan maupun terkait prosedur pelayanan telah sesuai dengan peraturan yang telah ditetapkan. Pemahaman pegawai dalam melayani masyarakat telah sesuai dengan prosedur pelayanan yang telah diterapkan pada pelaksanaan pelayanan pertanahan di hari biasa.

Kemampuan petugas dalam pelaksanaan pelayanan pada Program One Day Service sudah sesuai dengan apa yang diharapkan masyarakat, yaitu dapat memberikan pelayanan kepada masyarakat secara informatif, cepat, dan cermat. Selain itu dengan adanya pelayanan melalui program tersebut tidak lantas menjadikan kurangnya kualitas kemampuan pegawai di Badan Pertanahan Nasional Kota Malang yang dapat berakibat pelayanan pertanahan pada Program One Day Service tidak maksimal. Hal tersebut disebabkan karena pada dasarnya setiap petugas yang memberikan pelayanan pada program ini sama dengan petugas yang memberikan pelayanan pertanahan pada hari biasa. 
Sehingga tidak diragukan lagi kemampuann petugas dalam melayani masyarakat untuk menyelesaikan pelayanan melalui Program One Day Service dapat berjalan sesuai dengan apa yang diharapkan.

\subsubsection{Kesesuaian Antara Kelompok Masyarakat dengan Organisasi Pelaksana}

a) Adanya Kejelasan Persyaratan yang Harus
Dilengkapi
Pelaksanaan pelayanan pertanahan melalui Program One Day Service di Badan Pertanahan Nasional Kota Malang tidak dapat terlepas dari persyaratan dan prosedur pelayanan. Persyaratan pada pelayanan pertanahan melalui Program One Day Service sama dengan persyaratan pada pelayanan pertanahan dihari biasa. Adapun yang membedakan pelayanan pertanahan melalui Program One Day Service dengan pelayanan dihari biasa, yaitu waktu penyelesaian dokumen permohonan pada program ini dapat diselesaikan dalam jangka waktu 1-8 jam pelayanan dan berlaku setiap hari rabu. Kemudian persyaratan pelayanan pertanahan melalui Program One Day Service sama dengan persyaratan pelayanan pada pelayanan hari biasa. Adapun persyaratan-persyaratan yang harus dipenuhi pada saat permohonan dokumen pelayanan melalui program One Day Service, antara lain sebagai berikut (Badan Pertanahan Nasional Republik Indonesia, 2019):

1) Pengecekan sertifikat tanah

- Formulir permohonan yang telah diisi dan ditandatangani oleh pemohon;

- Fotocopy identitas pemohon (KTP) yang telah dicocokkan dengan aslinya oleh petugas loket pelayanan One Day Service;

- Sertifikat Hak Atas Tanah yang bersangkutan; dan

- Surat Pengantar dari PPAT untuk kegiatan peralihan/ pembebasan hak dengan akta PPAT.

2) Roya

- Surat permohonan atau lampiran 13 (yang tersedia di Kantor Pertanahan Nasional Kota Malang);

- Surat sertifikat tanah asli;

- Sertifikat Hak Tanggungan asli;

- Fotocopy KTP dan KK pemilik tanah yang telah dicocokan dengan aslinya oleh petugas loket atau legalisir oleh pejabat yang berwenang;

- Surat Permohonan roya dari bank atau kreditur yang diberikan saat pelunasan cicilan; dan

- Surat perubahan nama bila ada pergantian nama institusi kreditur.

3) Peralihan Hak

- Surat permohonan yang ditandatangani oleh pemohon;
- Sertifikat asli dan fotocopy sertifikat;

- Akta peralihan hak (bila fotocopy atau legalisir);

- Fotocopy KTP dan KK pemilik tanah yang dilegalisir oleh pejabat yang berwenang;

- Fotocopy SPPT PBB; dan

- Surat persetujuan dari pemegang Hak Tanggungan apabila dibebani Hak Tanggungan.

b) Adanya Ketepatan Waktu

Ketepatan waktu dalam pelaksanaan pelayanan One Day Service di Badan Pertanahan Nasional Kota Malang; menjadi prioritas utama dalam pelaksanaan pelayanan pertanahan. Waktu penyelesaian pelayanan pertanahan dipengaruhi oleh tingkat kualitas pelayanan yang diberikan oleh petugas loket. Tujuan dari adanya program One Day Service adalah untuk mempersingkat waktu pelayanan pertanahan dan dapat memberikan pelayanan secara maksimal. Oleh sebab itu agar dapat memberikan pelayanan sesuai dengan waktu yang telah ditetapkan, maka petugas loket memberikan batasan kuota pemohon pelayanan melalui program ini untuk memaksimalkan pelayanan pertanahan.

Ketepatan waktu yang diberikan petugas untuk menyelesaikan permohonan dokumen oleh masyarakat telah sesuai dengan tujuan dari program ini, yaitu dapat menyelesaikan dokumen pelayanan dalam satu hari. Namun kekurangan dalam pelaksanaan pelayanan Program One Day Service adalah waktu pelayanan pada program ini hanya dilakukan setiap hari Rabu, sehingga masyarakat membutuhkan adanya pelayanan seperti program ini di hari lain. Program One Day Service dinilai memberikan kemudahan bagi masyarakat yang akan mengurus sertifikat tanah. Adapun hal lain yang menjadi motivasi masyarakat untuk mengajukan permohonan dokumen melalui pelayanan One Day Service adalah penyelesaian dokumen dapat diselesaikan dalam waktu satu hari untuk pelayanan pengecekan sertifikat tanah, roya dan peralihan hak.

\subsection{Kualitas Pelayanan One Day Service di Badan Pertanahan Nasional Kota Malang}

Pelaksanaan pelayanan kepada masyarakat menjadi salah satu tugas utama dari pemerintah. Begitu juga dengan Badan Pertanahan Nasional, memliki tugas utama, yaitu memberikan pelayanan pada bidang pertanahan. Sistem pelayanan yang buruk akan memberikan dampak negatif bagi masyarakat ataupun pemerintah. Maka dari itu penyelenggaraan pelayanan harus memberikan pelayanan yang berkualitas. Kualitas pelayanan dapat dilihat dari beberapa dimensi, yaitu dimensi tangibles, reability, responsiveness, assurance dan emphaty. Demikian pula dengan kualitas pelayanan One Day Service, dapat tinjau dari kelima elemen tersebut. 


\subsubsection{Kualitas Pelayanan Pertanahan dari Dimensi Tangibles (Bukti Langsung)}

Ditinjau dari dimensi Tangibles, maka kualitas pelayanan publik pada pelaksanaan pelayanan melalui Program One Day Service di Badan Pertanahan Nasional Kota Malang; dapat dikatakan sudah banyak unsur yang dipenuhi walaupun masih belum optimal. Masih terdapat kekurangan dibeberapa bagian. Secara fisik dapat dilihat dari proses sosialisasi atau penyuluhan pada Program Pelayanan One Day Service, yaitu penampilan petugas, kualitas pelayanan aparatu dalam melayani masyarakat, serta kenyamanan tempat pelayanan. Ketiga elemen ini penting dalam memberikan pelayanan kepada masyarakat. Ketiga fenomena yang ada dilapangan yang berkaitan dengan Dimensi Tangibles; menunjukkan bahwa kegiatan penyuluhan atau sosialisasi Program One Day Service masih belum optimal karena masih ada masyarakat yang tidak mengetahui persyaratan dalam pengurusan sertifikat tanah. Selain itu masyarakat juga masih belum sepenuhnya mengetahui mengenai prosedur pelayanan pada pelayanan One Day Service di Badan Pertanahan Nasional Kota Malang.

\subsubsection{Kualitas Pelayanan Pertanahan dari Dimensi Reability (Kehandalan)}

Kualitas pelayanan pertanahan di Kantor Badan Pertanahan Kota Malang melalui Program One Day Service juga dapat dinilai dari reliability atau keandalan pelayanan kepada masyarakat. Dimensi ini terdiri dari keandalan standard operasional prosedur pelayanan pertanahan dan keandalan petugas dalam memberikan pelayanan kepada masyarakat. Berdasarkan hasil penelitian, maka penilaian terhadap dimensi ini sudah cukup baik meskipun masih ada kekurangan dalam prosedur pelayanan yang cukup berbelit-belit. Kemudian keandalan petugas dalam menyelesaiakan pelayanan dalam sehari dapat dikatakan sudah sesuai dengan target yang telah diatur dalam peraturan mengenai pelayanan One Day Service.

\subsubsection{Kualitas Pelayanan Pertanahan dari Dimensi Responsiveness (Daya Tanggap Petugas)}

Penilaian kualitas pelayanan One Day Service di Badan Pertanahan Nasional Kota Malang juga dapat dilihat dari dimensi responsiveness atau daya tanggap petugas dalam memberikan pelayanan. Dalam menganalisis hal tersebut dilakukan dengan melihat kecepatan petugas dalam menyelesaikan berkas permohonan pelayanan. Selain itu itu juga ditinjau dari aspek kesederhanaan dan kemudahan prosedur pelayanan yang ada. Berdasarkan pengamatan, maka kemudahan dan kesederhanaan prosedur pelayanan sudah sesuai dengan SOP. Namun meski demikian, SOP dalam pelayanan One Day Service masih dirasa rumit dan berbelit-belit, sehingga petugas Badan Pertanahan Nasional Kota Malang menyediakan loket khusus untuk memberikan informasi terkait persyaratan dan prosedur pelayanan pada pelayanan One Day Service.

Adapun rumit dan kompleksnya SOP tersebut disebabkan keterbatasan kewenangan Badan Pertanahan Nasional Kota Malang; mengingat SOP tersebut dirancang langsung oleh pemerintah pusat. Kondisi demikian menjadi salah satu kendala yang sebetulnya dapat dicari jalan keluarnya, yaitu dengan memberikan kewenangan kepada Badan Pertanahan Nasional Kota Malang untuk mengeluarkan persyaratan atau prosedur SOP yang sesuai dengan keadaan masyarakat khususnya masyarakat Kota Malang.

\subsubsection{Kualitas Pelayanan Pertanahan dari Dimensi Assurance (Kepastian atau Jaminan pelayanan)}

Penilaian kualitas pelayanan publik melalui Program Pelayanan One Day Service pada Badan Pertanahan Nasional Kota Malang; dapat dilihat dari kepastian pelayanan yang diberikan. Atau dengan kata lain, pelaksanaan pelayanan One Day Service di Badan Pertanahan Nasional Kota Malang dapat dilihat melalui ketepatan waktu penyelesaian berkas pelayanan pertanahan. Waktu yang ditentukan dalam pelayanan ini telah ditetapkan dalam Peraturan Kepala Badan Pertanahan Nasional Republik Indonesia Nomor 1 Tahun 2010 mengenai Penyederhanaan dan Percepatan Standar Operasi Pengaturan dan Pelayanan (SPOPP). Dalam peraturan tersebut ditentukan waktu penyelesaian pada pelayanan pengurusan sertifikat tanah melalui Program One Day Service berkisar selama 1-8 jam kerja.

Berdasarkan pengamatan dilapangan, maka pelayanan One Day Service di Badan Pertanahan Nasional Kota Malang sudah berjalan sesuai dengan peraturan yang berlaku, yaitu penyelesaian pelayanan berkas hanya dalam satu hari saja.

Adapun kendala dalam penyelesaian berkas dalam tempo satu hari adalah masyarakat tidak memahami prosedur yang ada, sehingga terkadang masih ada masyarakat yang tidak memenuhi persyaratan lengkap pengurusan sertifikat tanah.

\subsubsection{Kualitas Pelayanan Pertanahan dari Dimensi Emphaty (Empati/ Kepedulian)}

Aspek dimensi empati dapat ditinjau dari urutan prosedur pelayananan dan kemudahan dalam penggunaan saran dan prasarana yang disediakan oleh pemerintah. Pelayanan One Day Service di Badan Pertanahan Nasional Kota Malang telah menggunakan sistem pelayanan satu atap, sehingga memberikan kemudahan masyarakat untuk melakukan pembayaran secara langsung dan tidak langsung melalui sistem perbankan. Hal tersebut salah satunya dibuktikan 
dengan keterangan dari pemohon yang sudah melakukan pelayanan pada Program One Day Service di Badan Pertanahan Nasional Kota Malang.

Urutan prosedur pelayanan One Day Service di Badan Pertanahan Nasional Kota Malang juga sudah diterapkan sesuai dengan peraturan yang berlaku, sehingga tidak ada prosedur yang tidak dilewati oleh masyarakat jika melakukan pelayanan dengan menggunakan program sehari jadi ini.

Kemudahan prosedur yang masih dirasa berbelitbelit oleh masyarakat menjadi sebuah kritikan bagi pegawai pertanahan di Kota Malang, karena pada dasarnya pelayanan pertanahan pada Program One Day Service menjadi salah satu program yang menerapkan kecepatan dalam pelayanan dengan memotong alur administrasi pertanahan. Akan tetapi praktek dilapangan menunjukkan prosedur pelayanan yang masih dirasa tidak memberikan kemudahan bagi masyarakat. Kondisi demikian menimbulkan polemik yang kompleks dalam dimensi emphati pada kualitas pelayanan pertanahan melalui Program One Day Service.

Kemudahan prosedur dalam dimensi ini masih belum terlihat jelas dan masih berbelit, hal tersebut dapat dilihat dari masih ada masyarakat yang tidak mengetahui mengenai persyaratan dan prosedur pelayanan sesuai dengan SOP yang berlaku, sehingga tidak jarang ada pemohon yang sudah sampai diloket kemudian berkas yang diajukan tidak dapat diproses karena terdapat persyaratan yang kurang, sehingga membuat masyarakat kecewa.

Oleh karena itu dibutuhkan penyederhanaan SOP dalam pelayanan One Day Service mengingat persyaratan pelayanan dirasa masih menyulitkan masyarakat. Kemudian yang tidak kalah penting adalah peran masyarakat untuk mendapatkan informasi dalam pelayanan One Day Service agar proses pelayanan dapat dipercepat.

\subsection{Faktor Pendukung dan Penghambat dalam Implementasi Program Pelayanan One Day Service di Badan Pertanahan Nasional Kota Malang}

\subsubsection{Faktor Pendukung}

Kesiapan petugas dalam memberikan pelayanan melalui Program One Day Service menjadi salah satu hal terpenting dalam memberikan pelayanan kepada masyarakat. Petugas dituntut untuk dapat menyelesaikan seluruh berkas permohonan masyarakat dalam kurun waktu satu hari saja. Hal tersebut merupakan salah satu wujud program percepatan pelayanan yang menjadi bagian dari reformasi birokrasi sesuai dengan Peraturan Kepala Badan Pertanahan Nasional Republik Indonesia Nomor 1 Tahun 2010.
Kesiapan petugas dalam memberikan pelayanan dalam waktu satu hari sudah berjalan dengan baik dan sesuai harapan masyarakat yang menginginkan pelayanan yang cepat dan cermat serta berkualitas. Kesiapan petugas dalam pelayanan pertanahan didukung dengan kualitas sumber daya manusia yang terlatih dan kompeten. Hal tersebut terlihat saat petugas memberikan pengarahan dan penjelasan mengenai prosedur pelayanan/ SOP kepada masyarakat.

Kesiapan fasilitas atau infrastruktur yang mendukung pelaksanaan pelayanan adalah tersedianya loket khusus pelayanan One Day Service, sehingga tidak bercampur dengan pelaksanaan pelayanan yang ada pada loket di hari biasa. Kemudian kenyamanan ruang tunggu masyarakat di Kantor Badan Pertanahan Nasional menjadi salah satu upaya pemerintah untuk memberikan pelayanan pertanahan yang berkualitas. Ruang tunggu tersebut dilengkapi dengan jumlah kursi yang banyak serta tersedianya Air Conditioner (AC).

Faktor pendukung selanjutnya adalah kesiapan sistem komputerisasi juga menjadi bagian terpenting dalam pelayanan ini. Kesiapan komputerisasi merupakan indikator penting agar tujuan dari pelaksanaan program ini dapat terpenuhi.

\subsubsection{Faktor Penghambat}

Salah satu hambatan pelaksanaan pelayanan pertanahan melalui Program One Day Service di Badan Pertanahan Nasional Kota Malang adalah masih adanya berkas pemohon masyarakat yang tidak lengkap atau tidak sesuai dengan persyaratan yang ada. Faktor penghambat lainnya dalam pelaksanaan pelayanan pertanahan melalui program One Day Service, yaitu sistem komputerisasi yang dimiliki kadang lambat dalm pengoperasiannya.

Faktor penghambat lainnya berasal dari masyarakat sebagi pemohon. Dalam pelaksanaan pelayanan pertanahan melalui Program One Day Service terkadang masyarakat yang mengajukan permohonan tidak dapat diproses dikarenakan persyaratan yang diminta belum seluruhnya terpenuhi. Petugas loket pun secara otomatis harus menjelaskan seluruh persyaratan kepada pemohon. Namun terkadang masyarakat sebagai pemohon kurang dapat memahami, sehingga menyita waktu petugas loket yang terikat dengan jadwal satu hari pelayanan dalam Program One Day Service. Selain itu, adanya sikap emosional dari pemohon yang cukup menganggu berlangsungnya proses permohonan.

\section{Kesimpulan}

Berdasarkan analisis yang telah dilakukan, maka dapat ditarik kesimpulan, antara lain sebagai berikut:

a) Implementasi Program Pelayanan One Day Service di Badan Pertanahan Nasional Kota Malang telah 
sesuai dengan apa yang dibutuhkan masyarakat yang selama ini mengeluhkan atas pelayanan pertanahan yang lama dan berbelit-belit. Tujuan dari program ini adalah memberikan percepatan pelayanan pertanahan sesuai dengan apa yang diharapkan masyarakat. Selain itu, kemampuan pegawai dalam memberikan pelayanan pada program ini tidak diragukan lagi karena petugas telah terbiasa menyelesaiakan permohonan pelayanan pertanahan dihari biasa, sehingga penyelesaian permohonan tidak mengalami hambatan yang berarti. Kemudian kemampuan petugas dalam memberikan pelayanan, ketepatan waktu penyelesaian pelayanan juga menjadi prioritas dalam pelaksanaan pelayanan pertanahan melalui program ini. Ketepatan waktu dalam pelayanan One Day Service telah sesuai dengan tujuan program ini yang merupakan salah satu upaya percepatan pelayanan pertanahan oleh Badan Pertanahan Nasional Kota Malang;

b) Faktor pendukung dalam pelaksanaan pelayanan ini adalah kesiapan petugas dalam memberikan pelayanan kepada masyarakat, kesiapan fasilitas yang ada di Badan Pertanahan Nasional Kota Malang dengan adanya ruang tunggu yang nyaman dan aman. Kemudian kesiapan sistem komputerisasi dalam pelayanan One Day Service di Badan Pertanahan Nasional Kota Malang; telah berjalan sesuai dengan yang diharapkan masyarakat, yaitu dokumen permohonan dapat diinput sesuai dengan waktu yang telah ditentukan, yaitu cukup satu hari kerja; dan

c) Faktor penghambat dalam pelayanan pertanahan Program One Day Service, antara lain masih adanya berkas pemohon yang tidak lengkap sehingga menghambat penyelesaian berkas permohonan. Kemudian faktor penghambat lainnya adalah sikap emosional masyarakat pada saat berkas yang diajukan tidak dapat diselesaikan oleh petugas karena adanya persyaratan yang tidak terpenuhi. Hambatan yang terakhir dalam pelaksanaan pelayanan melalui Program One Day Service adalah sistem komputerisasi yang menghambat penyelesaian berkas pemohon yang disebabkan oleh tingkat kecepatan sistem komputer yang dirasakan kurang memadai.

\section{Daftar Pustaka}

Afrizal. (2009). Analisis Perekonomian Kabupaten Padang Pariaman Tahun 2007. Skripsi, Jurusan Ilmu Ekonomi Studi Pembangunan Fakultas Ekonomi Universitas Muhamadiyah, Surakarta.

Akib, Header., \& Tarigan, Antonius. (2008). Artikulasi Konsep Implementasi Kebijakan: Perspektif, Model dan Kriteria Pengukurannya. Jurnal Baca
Agustus, Vol. 1, pp.1-19.

Alamsyah, D. (2011). Manajemen Pelayanan. Nuha Medika, Yogyakarta.

BPN RI. (2019). One Day Service. Tersedia pada https://www.atrbpn.go.id/Publikasi/Inovasi/Layan an-1-Hari-Selesai-One-Day-Service [Diakses pada 15 Februari 2019].

Departemen Pendidikan Nasional RI. (2008). Kamus Bahasa Indonesia. Jakarta: Departemen Pendidikan Nasional RI.

Dwiyanto, Agus. (2010). Manajemen Pelayanan Pubik: Peduli, Inklusif dan Kolaborasi (Edisi Kedua). Gajah Mada University Press, Yogyakarta.

Effendi, Bachtiar. (1993). Pendaftaran Tanah di Indonesia dan Peraturan - peraturan Pelaksanaannya. Penerbit Alumni, Bandung.

Grindle, Merielle S. (1980). Politics and Policy Implementation in the Third World. New Jersey: Princeton University Press.

Herdiansyah, Haris. (2010). Metodologi Penelitian Kuantitatif. Jakarta: Salemba Humanika.

Miles, M.B., Huberman, A.M., \& Saldana, J. (2014). Qualitative Data Analysis, A Methods Sourcebook, Edition 3. USA: Sage Publications.

Pasolong, Harbani. (2013). Kepemimpinan Birokrasi. Bandung: CV. Alfabeta.

Ratminto., \& Atik Septi Winarsih. (2006). Manajemen Pelayanan. Pustaka Pelajar, Yogyakarta.

Riggs, Fred W. (2005). Administrasi Negara-negara Berkembang- Teori Masyarakat Prismatis. Jakarta: Rajawali.

Rohman, Arif. (2009). Memahami Pendidikan dan Ilmu Pendidikan. Yogyakarta: Laksbang Mediatama.

Samosir, Z. Z. (2005). Pengaruh kualitas Pelayanan Terhadap Kepuasan Mahasiswa Menggunakan Perpustakan USU. Jurnal Studi Perpustakaan Dan Informasi, Vol. 1(1), pp.28-36.

Setyaningrum, Erna. (2009). Inovasi Pelayanan Publik. Surabaya: Medika Aksara Globalindo.

Syukur, Abdullah M. (1988). Perkembangan dan Penerapan Studi Implementasi. Jakarta: Lembaga Administrasi Negara RI

Wibawa, dkk. (1994). Kebijakan Publik. Intermedia: Jakarta. 